\title{
AN EXPERIENCE AIMED AT PROMOTING VERNACULAR BUILDING CULTURE IN SUSUDEL (ECUADOR)
}

\author{
G. Barsallo ${ }^{1, *}$, F. Cardoso ${ }^{1}$, L. Vazquez ${ }^{1}$ \\ ${ }^{1}$ CPM project - University of Cuenca, Av. 12 de Abril y Loja, Cuenca - Ecuador \\ (gabriela.barsallo, fausto.cardoso, lorena.vazquez)@ucuenca.edu.ec
}

Commission II - WG II/8

Keywords: Workshop, Small architects, Participation, Susudel, Values

\begin{abstract}
The richness of the historical landscape environments of the popular architecture which is often built with vernacular systems whose technology and knowledge are transmitted from generation to generation through practice, suffers a series of threats caused by the irruption of new architecture models and the use of industrialized materials. Also the social factors have built stigmata and contempt or undervaluation for traditional ways of solving the habitat or architecture of community interest such as communal houses, temples, etc. This has caused a loss of quality and personality in the environments in which rural and marginal urban communities live in ecuadorian territory. One of the factors clearly identified as driving this breakdown of the natural process of loss of wisdom and knowledge, has been the distancing of new generations from what their parents do or did. Many times falsely articulated to a denial of local culture itself and ostentation on the basis of architecture unrelated to the place. With these considerations as a backdrop, a workshop for adults and children was set up. The objective was to build intergenerational bridges and to foster an appreciation of vernacular architecture, jointly discovering the benefits and the nobility of this way of doing architecture, and articulating it with the patrimonial values of the place. This article analyzes an experience applied between the years 2018 and 2019, in the community of Susudel, in Ecuador.
\end{abstract}

\section{INTROCUCTION}

The community of Susudel is located in the southern Andes of Ecuador, on the southern edge of the Azuay province, 85 kilometers from Cuenca. This site keeps a relevant cultural landscape that combines its plains, valleys and hills, with architecture that, from very remote times, was defined in its personality, morphology, design and application of local materials. In fact, this vernacular architecture has almost exclusively applied materials of the sector in its construction, such as wood and earth (adobes, bricks, colors), which strengthen the conformation of a delicate rural landscape of high aesthetic value, but also allow reading the socioeconomic dimension of the human settlement. For these reasons, among others, in 2013 its consolidated area was protected as Cultural Heritage of the Ecuadorian State. This human settlement has a history that goes back to pre-Hispanic times with the Cañaris ${ }^{1}$ and to colonial times.

The modern consolidation of this rural parish arises from the existence of a huge colonial hacienda, which was one of the

* Corresponding author

Native pre-Inca community from the territory of Ecuador, mainly located in the current provinces of Cañar and Azuay.

2 Latifundium is a large agricultural farm that belongs to a single owner.

Huasipungo is a piece of land that in the past the "master" gave to the native so that he could carry out agricultural or pastoral work, in exchange for the work that the indigenous himself had to do for the benefit of the landowner. Encyclopedia of Ecuador. http://www.enccyclopediadelecuador.com/historia-del-

ecuador/huasipungo / (last accessed on December 20th, 2019)

4 The scaramuza game is a staging with cavalry in which a group of riders and guides are representing several tasks in a square with the musical frame of the chirimía, percussion and village band; With special musical tones, they play creating different tasks. The loa, the challenge and the counterchallenge are characters that are part of the scaramuza and intervene with their verses before the game, to praise the patron saints, thank the priostes and devotees for sponsoring the largest latifundia ${ }^{2}$ in the country whose internal organization was structured based on huasipungos ${ }^{3}$ for the occupation of local indigenous communities. As part of the typology of this architectural and production complex, a chapel was also built in the 18th century, which is located next to a public space called "Plaza de las Escaramuzas". The hacienda maintained its integrity until the implementation of the agrarian reform in the $60 \mathrm{~s}$ of the twentieth century and with the redistribution of land, peasants accessed the property through concessions established by the state (Cardoso, 2015). The distance of the granted properties and the will of the community to remain united aroused the additional granting of small properties in the immediate vicinity of the main house of the hacienda. This is how the calle de Posesiones (or Calle tres de noviembre) is consolidated, with a set of vernacular dwellings that "constitute the reflection of the life of the peasant man, separated from the ideas of comfort and convenience generated in the city" (Vélesela, 2008).

Another mechanism of social cohesion that still persists in this Andean region is the minga ${ }^{5}$. Susudel, until today, is a living

party, draw attention to the authorities, youth and adults, and to humorously name the most popular and relevant characters in each community. National Institute of Cultural Heritage, INPC.

The minga is defined as collective unpaid work for the common interest of the community. The minga (minka in the traditional Andes language Quechua) is a pre-Columbian tradition for purposes of social or reciprocal nature, currently being used in various Latin American countries, such as Colombia, Peru, Ecuador, Bolivia, Chile and Paraguay. In Europe exists an equivalent known as "procomun". It can have different purposes, such as the building of a house or agricultural activities. The minga does not need obligations nor incentives for its execution, since all of its participants are beneficiaries alike. It is a form of communal work, in which all work together for something beneficial to all participants, and where the participants contribute with their labor in exchange for collective benefits (Ferrari, 2004; Cachiguango, 2006; García et al., 2015; Wikipedia, 2018). 
example of this collaborative practice. Although that older farmers are the maintainers of this practice, with an ever lower involvement of the new generations.

In the most recent years, the transfer of knowledge has had to face the consequences of a marked intergenerational rupture, which results from the speed with which modern life is imposed: the impact of migration and the exacerbation of consumerism in the new generations has produced of generational discontinuity, (Cardoso, 2015) To which is added the lack of knowledge and conscious assessment of their own material and intangible assets. Also a false idea of progress in which the ideas of the migrant drive a renunciation to local cultural features, in the midst of which a growing dependence on technology, and the digital world, has caused traumas in the fragile balances of the rural environment. This new sociocultural reality affects the vernacular and popular architecture in a significant way. The seductive lifestyles carried by communications technology and a weak local attitude towards culture, consolidate new paradigms and life models that are assumed uncritically by the new generations. This new generations, associate traditional architecture with poverty and poor quality of life, renouncing the value of traditional construction materials and techniques, for the benefit of assignments based on architecture built with industrialized processes and products.

The University of Cuenca through the Faculty of Architecture and Urbanism and its Ciudad Patrimonio Mundial research project $^{6}$, since 2007 , has worked consistently in this community with a view to establishing social processes for the recovery of its heritage values. In several experiences undertaken, the academy is linked through the Heritage Conservation Workshop, a chair in which students and teachers from the fifth year of the Architecture degree participate, with community work. This is how, in 2011, the first Campaign for the Maintenance of Vernacular Housing was executed. This intervention that had the academic, technical and administrative contribution of the University of Cuenca, through the intervention project, the technical support of conservative architects and the management of participation of public and private companies. In addition to generating the active participation of the community in the development processes of the studies and works, was involved in 48 heritage buildings, a project that had a strong national visibility, which opened spaces for future collaborations.

Between 2012 and 2013, in response to a "municipal proposal to change the tombs to burial mounds of centuries-old tradition, for tombs with niches built in height, which assumed urban models, to which was added the demolition of the cemetery chapel". (Cardoso, 2016) the community, appropriated to its heritage, requested a new action with the support of the University of Cuenca. As a result, a shared process was generated by applying the Maintenance Campaigns model, with the participation of the parish communes: the small chapel located inside the cemetery, the arch and the perimeter walls of the enclosure, in addition to the general cleaning of tumuli of land were the tangible results of this work. This experience meant the consolidation of this experimental model applied in 2011.

Again, minga processes were activated, the participation of the community was fundamental for adobe production, construction and recovery of thatched structures, woodwork, and even in food preparation and grants of supplies which tested the ability to work in community.

6 The vlirCPM project (VlaamseInteruniversitaireRaad - City Preservation Management), in coordination with the consortium of Flemish universities, lasted from 2007 to 2018. Its objective was to develop scientific bases and provide high-level education to
After these initiatives, several collaborations have been generated through thesis and postgraduate projects related to the recovery and assessment of traditional techniques and knowledge (colored lands and bricks), with the close look of the Ciudad Patrimonio Mundial Project towards the site of rural study which is Susudel. One of these initiatives is the one that was executed during the years 2018 and 2019. It was focused on the study of the architectural complex of the Casa Hacienda, a project that was developed within the framework of the Workshop on Heritage Conservation. Analyzed concerning several aspects, but especially emphasizing the valuation of assets, on the basis of a community and social reading. As a result of this exercise, values come to light that undoubtedly respond to life practices, potentialities, and problems, which are collected through workshops with the community where the informants are older adults or seniors.

In this context, a work strategy was defined in two parallel cocreation workshops, in which the inhabitants of the community assumed the role of designers and builders, guided by researchers from the University of Cuenca and the University from Hasselt (Belgium). The idea of working together in physically close and eventually shared spaces forged interaction relations between the two groups, normally distant and without shared interests, through the Small Architects, Great Architects workshop, with own objectives for each group, but with the common goal to build intergenerational bridges, in a shared work experience that lasted a week.

\subsection{Pedagogy as a masonry or architectural career}

The value of heritage is born in the socio-cultural processes and the capacity of the subjects to reinterpret it. That is, heritage is born from the construction of a group identity, from a space of collective complicity that seeks to understand heritage from a social and intergenerational perspective. Thus, heritage is conceived as an inclusive paradigm of generations. It is understood as the tangible and intangible imaginary and the traditional trades of this community. Specifically, the works related to construction with earth and its masonry works, allow to understand Susudel's heritage in its various facets and dimensions.

There are multiple variables in relation to labor activities related to construction in rural areas of Ecuador. But a common and recognizable constant throughout its territory, and especially strong in the Andean area, is that trades are learned on site, from generation to generation, masonry is learned from a brother or father, or from a recognized teacher with experience, because there is no school to be a bricklayer in Ecuador (Sánchez, 2012).

Although masonry is an occupation that will never disappear because houses and buildings will always be built, the trade applied to vernacular technologies is much more fragile because it depends on the will to build and invest resources in its application, because people know that it is complex and laborious, and needs patience and empirical knowledge, not written for its execution. The significant percentage of up to $21.83 \%$ of the economically active population corresponds to the sector of second-order trades such as construction by bricklayers, laborers or laborers, while $48.88 \%$ identifies as self-employed in the manufacture of bricks, in the more than one hundred artisan factories in the southern region of the province of Azuay. All

contribute to the objective of improving management of world heritage sites in southern Ecuador through the generation of tools and the dissemination of knowledge. It is currently known as the CPM project (Ciudad Patrimonio Mundial). 
members of the family, including children, are involved in this activity in different ways. Currently, just in the canton of Oña, about fifty families of the place are dedicated to this craft. (PDOT. Government Oña, 2019)

In this social and productive context, and accompanying several initiatives developed around the recovery of heritage by the University of Cuenca, it was proposed to develop a workshop focused on children. The main objective of assessing the use of earth by establishing intergenerational links, sowing interest in construction processes and challenges, stimulating creativity and linking children from small ages in a didactic way, working with materials such as adobe and wood and colored earth, which are abundant in the region. (Amaya et al., 2018)

\section{2. "SMALL ARCHITECTS" ADOBE CONSTRUCTION WORKSHOP FOR THE CHILDREN OF SUSUDEL}

\subsection{Methodology}

Several weeks prior to the development of the workshop, the participation of children of different ages was managed, with the support of the directors of the Susudel Educational Center summoning students of each of the levels of education. The organizing team convened a meeting explaining the activities, in which photographs of the buildings to be constructed were shown in scale. They also explained the general dynamics to the parents.

The University of Cuenca analyzed the best work dynamics in the workshop, choosing to create three work groups based on documentation developed by university students and researchers. Each group was responsible for building:

a) The chapel of the Community (scale 1:250) building that was part of the Casa Hacienda of Susudel, built in the 18th century in adobe technology. It has a material and intangible wealth of enormous importance for the community and for the national heritage. It is considered the most important rural chapel in the province of Azuay (Figure 4).

b) A house designed for the consolidated context (scale 1:50) conformed by a portal and allowing the expansion. This building is resolved in two floors, in which two independent areas are developed: the social area on the ground floor and the private area on the top floor; It also has an animal and laundry area in the back (Figure 5).

c) A house designed for the agricultural area (scale 1:50) organized around a central courtyard, distributed in three blocks of various functions: a block of bedrooms and bathroom, a social and kitchen block, and a service block that includes laundry, barn and pens for guinea pigs and chickens (Figure 6).

The buildings (b-c) are a housing proposal, resulting from a graduation work of the Faculty of Architecture of the University of Cuenca, which were co-designed with the community (using local adobe technology), based on the typologies of the sector, and giving answers to the requirements of traditional and modern life: spaces related to agricultural activities, animal care, livestock and artisanal manufacturing of products. (Gárate, Cardoso, 2018)

\subsection{Organization, preparation of materials}

The work of preparation and organization of the activities began several weeks before, with the participation of teachers, students and researchers, developing and simplifying technical plans at appropriate scales, for easy interpretation of children. This process had to take on the challenge of offering small tools that are easy to understand, without renouncing those that are classic in architecture: floors, elevations, cuts, etc. Even the foundations, whose importance was discussed in the process, were pre-drawn on wooden boards that served as the basis for the exercise.

The manual production of approximately 5,800 small bricks $(4 \times 2 \times 2 \mathrm{~cm})$ had an interesting process, for which a small production workshop was set up at the University of Cuenca; Several production dynamics were studied with serial and individual production molds, taking as reference a generic mold that makes it possible to obtain several small bricks. To do so, different activities were carried out: wooden frames were prepared for mass production as well as aluminum molds to define the rectangular shape of the small bricks; The raw material (sifted earth and generated mix) was prepared. As can be seen in figure 1. after manufacturing, the pieces, as in real production, followed their drying process and then were organized and packed for transfer to Susudel.
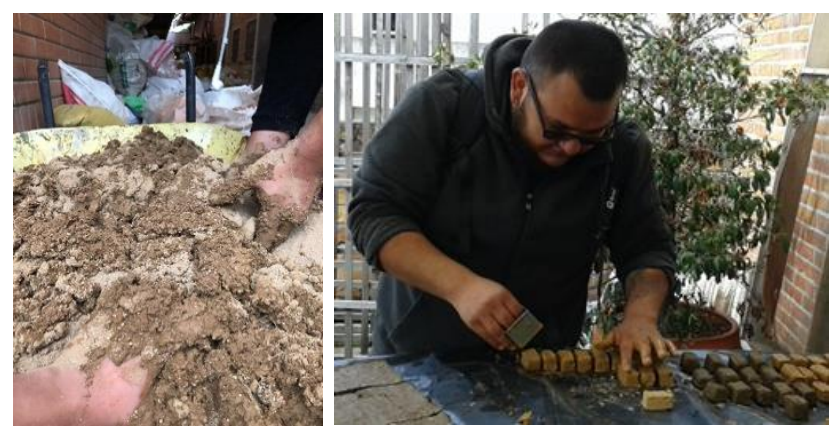

Figure 1.- Process of making bricks on a smaller scale. Author: Gabriela Barsallo 2018.

Although adobe was the main material, it was additionally necessary to prepare a kit of pieces of wood to develop mezzanine structures, roofs, portals, etc. which are considered important parts of constructing buildings.

Simultaneously, didactic material was prepared, to color, draw and identify which are the patrimonial characteristics of Susudel from the children's point of view. Thus, recreational activities were integrated into the learning process.

\subsection{Development of the Workshop}

This workshop was held between the twenty-second and twentysixth of July, 2019. 42 children and 10 adults participated in this workshop. The activity was planned for 5 days. The organization for the workshop required to work with three groups of participants, each of which was composed of $10-13$ children with the support of researchers from the Ciudad Patrimonio Mundial project. Each group was in charge of one building.

On the first day of activities, various group dynamics were developed, quickly integrating the children and inviting them to familiarize themselves with the work team and their new colleagues. 
The dynamics were developed combining game and learning. In these an explanation was offered of the construction systems and construction processes in vernacular architecture. Cementing: through a participatory process that included collecting small stones to stick them in the foundation area or, in other cases, draw them. The objective was to promote construction with materials from the environment, stimulating the creativity of the children; Walls: these were raised with small bricks. The children learned the processes of leveling bricks, the importance of interlocking bricks and corner solutions; They tested the use of earth mortar for laying bricks and how to anticipate the presence of openings, among other activities. In addition, assuming construction challenges, more complex structural principles were addressed with the construction of the transverse arch of the chapel. This was one of the challenges that surprised the participating children intensely: they never knew or imagined how an arch is constructed, but with a didactic explanation, a solution was reached among all (Figure 2).
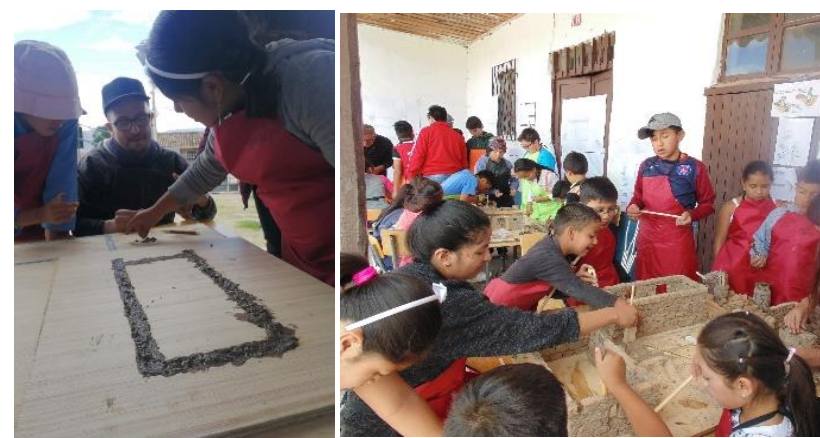

Figure 2. a) foundation construction, b) working groups. Source: Photographic Repository of the Ciudad Patrimonio Mundial project.
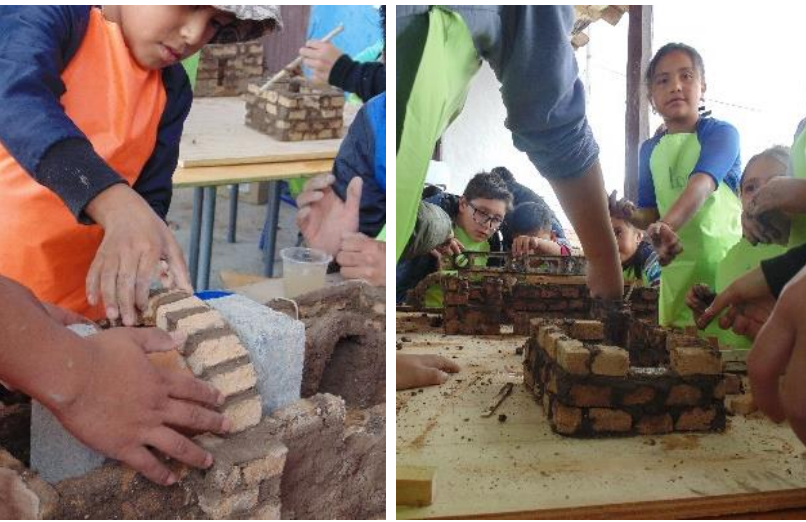

Figure 2. c) construction of the chapel arch, d) construction of walls (leveling, interlocking)

Source: Photographic Repository of the Ciudad Patrimonio Mundial project.

Another session focused on structures and finishes: each piece of wood has a role to play; Susudel's children learned about the way structures work and their assembly process. It was essential to improvise a small carpentry workshop on site, to prepare the structural pieces and furniture. For the finishing of walls, the children organized themselves autonomously, to be able to produce fine earth by means of sifting and then the production of a fine and consistent paste.

Noque. Accumulation of drying clay
Experimentation was key in the project and turned it into a playful experience in which adults were gradually included. Experiences also came from home: one of the children built a noque $^{7}$ which he had seen his father do in front of a construction with earth (Figure 3).

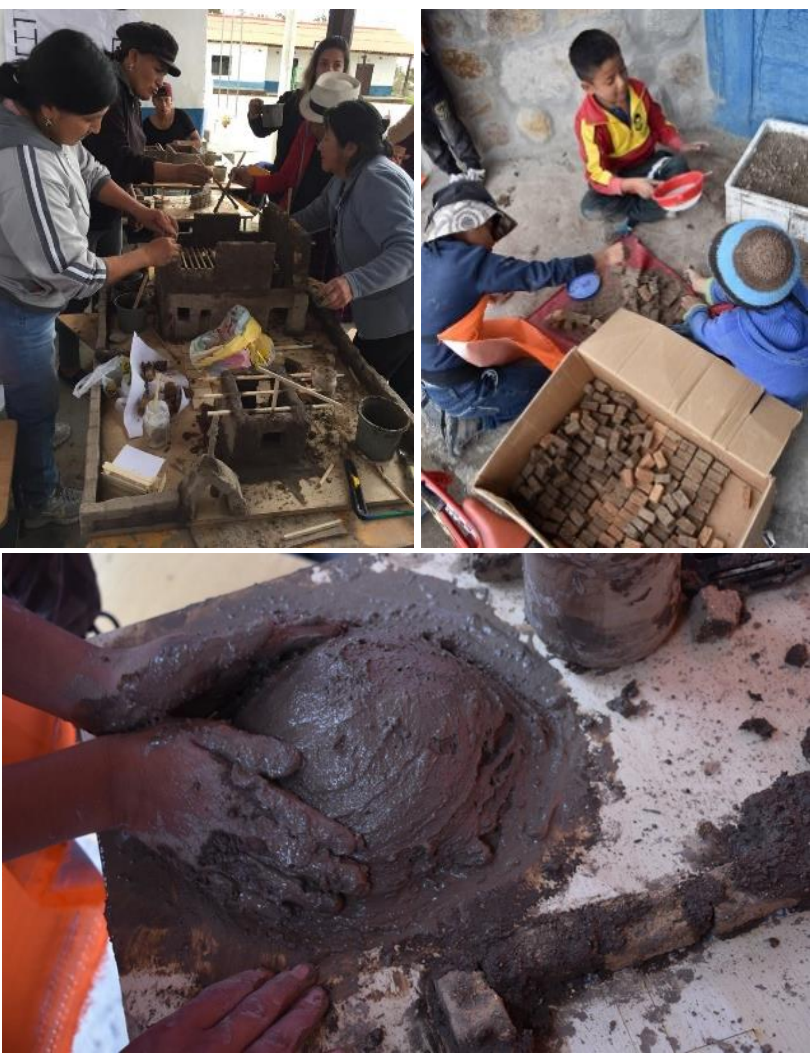

Figure 3. a) integration of adults to the workshop. b) laborious hands in the sifting of earth. c) missing photo of the mud noque.Source: Photographic Repository of the Ciudad Patrimonio Mundial project.

\section{RESULTS}

The construction in scale of the built heritage allows to strengthen the memory of Susudel's heritage. The proposal to bring, understand and build the church and buildings in a group of children, tries to desacralize the heritage, bringing people closer and understanding it from a pedagogical approach, which goes far beyond observation. In this exercise the rescue of ancestral construction techniques converges. Understanding how they did it creates a feeling of affiliation between the heritage property and the trade.

As a result of this experience, the possibility of weaving intergenerational relationships around architecture with earth was reaffirmed, along with boosting projects that promote the active participation of children and adults, the assessment and preservation of traditional constructive culture. Furthermore, it facilitates opportunities for children to develop their skills and sensitivity to vernacular architecture that in many parts of Ecuador is devalued and stigmatized and now begins to be rediscovered by many people, and largely by children.

The active participation of children sought to generate learning from practice, from a didactic work of recognition, assessment and reflection on vernacular architecture. 
Similarly, some other skills were promoted such as leadership and unexpected passion at work. In addition, in a closing session, which had an atmosphere of solemnity, inside the Chapel, the children presented their work experiences and sensibilities with aplomb.

The workshop emphasized values such as responsibility, and care and cleaning of tools and work. This was an essential task to create habits of discipline at work, and to ensure satisfactory continuation of the activities the following days.

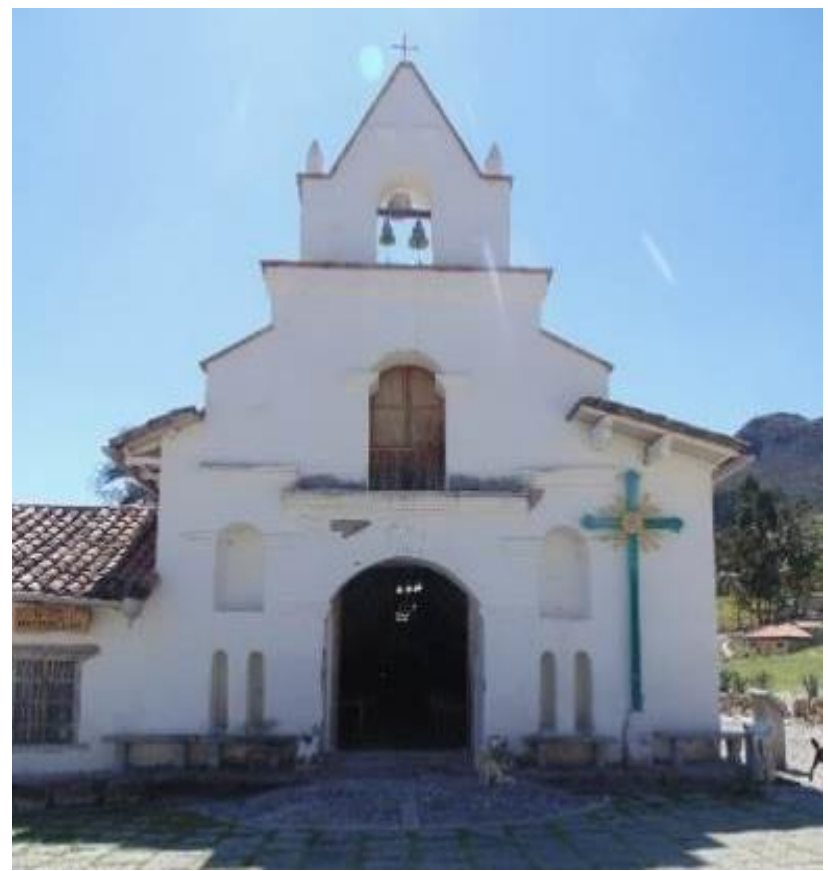

As a result, there is the construction of the buildings named above (Figures 4, 5 and 6) but without a doubt the best result that can be recognized is participation, social cohesion, teamwork and, above all, the equity valuation of construction techniques such as heritage buildings.

As an anecdote that strengthens the impression of the positive impact of this experience, it can be said that four months after the workshop, a boy appeared with his own chapel, built with the help of his brothers and father during his spare time.

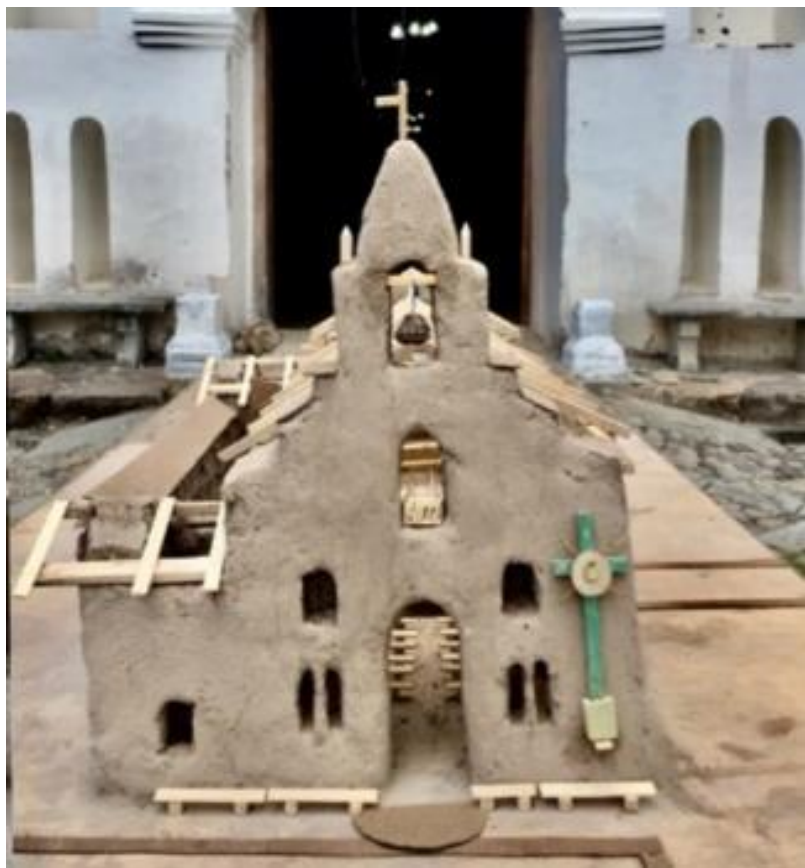

Figure 4. a) The community chapel. Source: Photographic Repository of the Ciudad Patrimonio Mundial project.
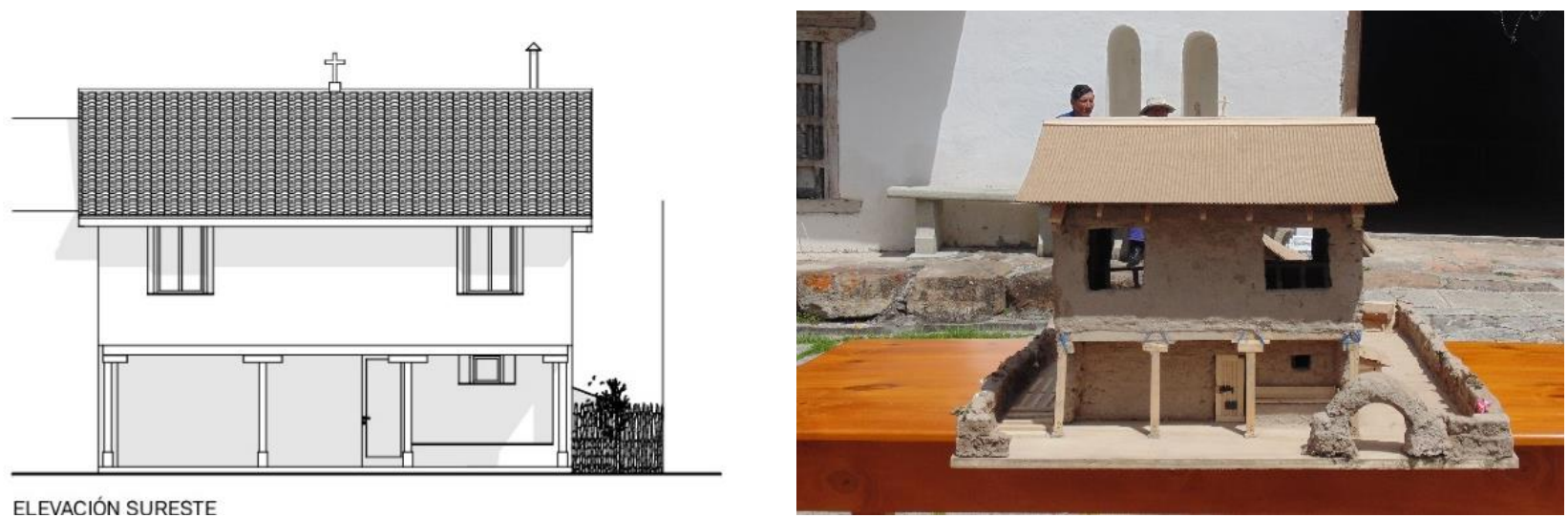

ELEVACIÓN SURESTE

Figure 5. b) House designed for the consolidated context. Source: Photographic Repository of the Ciudad Patrimonio Mundial project.

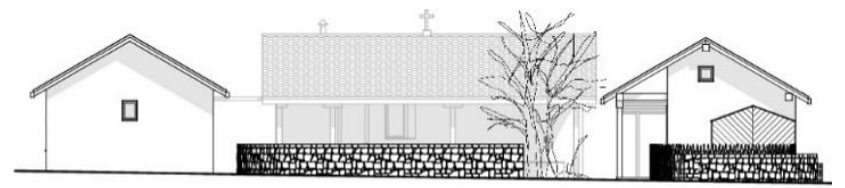

ELEVACIÓN NORTE

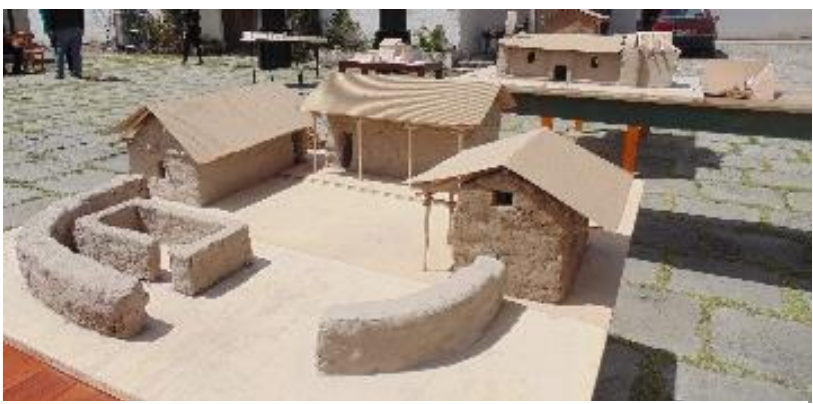

Figure 6. c) House designed for the agricultural area. Source: Photographic Repository of the Ciudad Patrimonio Mundial project. 
He recovered the plans and the bricks that were left over from the July workshop, and little by little, without any advice, he managed to build a model of the Susudel church. Apparently, the Workshop saw the birth of a new architect! (Figure 7)

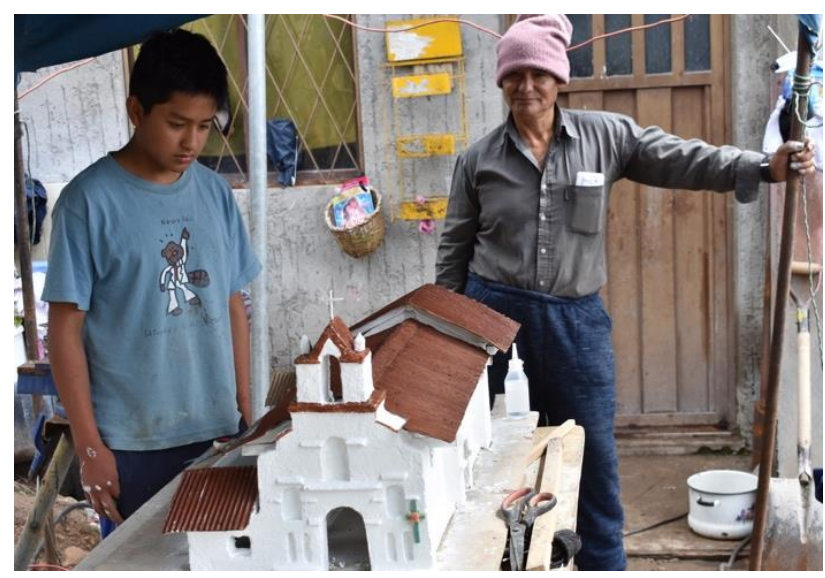

Figure 7. Four months after the workshop, a boy appeared with his own chapel. Source: Photographic Repository of the Ciudad Patrimonio Mundial project.

\section{CONCLUSIONS}

UNESCO expresses that the heritage is expressed in "works of its artists, architects, musicians, writers and sages, as well as anonymous creations, arising from the popular soul, and the set of values that give meaning to life. That is, the material and intangible works that express the creativity of that people." (UNESCO, 1982) Heritage is assumed as a source of inspiration and learning, it is a wonderful pedagogical instrument in which reproduction on a smaller scale can stimulate the learning of a traditional trade, which in the future can be a source of economic resources or a first seed for future architects.

Being current actors, understanding material and intangible heritage from practice, knowing that culture is dynamic and heritage has to be built and reinvented day by day, approaching the object itself, creating and re-creating it, fills the subject with a kind of empowerment. hen, what is understood, can be taken care of, protected and preserved with a pride to share it with other people, or with generations to come.

Culture, heritage and the use of its activations can contribute greatly to the progress of society and to strengthen its collective identity. Also, it promotes the inclusion of the community, weaves intergenerational bridges, stimulates the learning of traditional trades that can generate sources of work linked to the conservation of heritage or to venturing into innovation on its foundations. These activated processes from university experiences, in close connection with the communities, concerning the built heritage of Susudel and nearby cities such as Cuenca, seeks to show new generations the great possibilities that can be opened in ancestral trades, the need to rely on them for the protection of existing heritage, or for the creation of new elements, new relevant architecture and connected with cultural sites and each community's own sensibilities.

\section{REFERENCES}

Amaya-Ruiz, J., Ordóñez-Carpio, S., Salazar-Silva, I., AchigBalarezo, M. C., Peñaherrera-Palacios, C. Cardoso-Martínez, F., 2018. La producción de pintura en tierra como recurso endógeno en la provincia del Azuay, Ecuador. Estoa. Revista de la Facultad de Arquitectura y Urbanismo de la Universidad de Cuenca, 0(7), p. 93-102.

Cardoso, F., 2015. Plan Piloto de Conservación Preventiva aplicado a las viviendas de Susudel (2011-2012) y la intervención en el cementerio de Susudel (2013). Tierra, Sociedad, Comunidad, 15 SIACOT: Seminario Iberoamericano de Arquitectura y Construcción con Tierra, Cuenca - Ecuador, 9-13 November 2015., p. 337-350.

Cardoso, F., Achig-Balarezo, M., Vázquez, L., Barsallo, G., 2016. La Conservación Preventiva en Tierra en el sur del Ecuador. Terra Lyon 2016, Lyon - France, 2016., p. 136.

Cachiguango, L., 2006. La sabiduría andina en la fiesta y el trabajo. Cuaderno de investigación en Cultura y Tecnología Andina, N. 23. IECTA, Chile, 2006.

(Diario el comercio, 2012) Un albañil que aprendió su oficio de obra en obra, Cuenca - Ecuador.

https://www.elcomercio.com/tendencias/construir/albanil-queaprendio-oficio-de.html.

Ferrari, E., 2004. Reciprocidad, don y deuda. Relaciones y formar de intercambio en los Andes ecuatorianos. La comunidad de Pesillo. FLACSO, Sede Ecuador. Ediciones Abya-Yala, Quito Ecuador.

García, G., Cardoso, F., Van Balen, K., 2015. The Challenges of Preventive Conservation theory applied to Susudel, Ecuador. Reflections on Preventive Conservation Theories and Practices. Raymond Lemaire International Centre for Conservation, Leuven-Belgium, p. 117-129.

Plan de Desarrollo y Ordenamiento Territorial - Susudel (PDOT). Período 2009-2014. Available on: http://app.sni.gob.ec/snilink/sni/PORTAL_SNI/data_sigad_plus/sigadplusdocumentofin al/0160033440001_PDOT\%20Parroquia\%20 Susudel_30-102015_18-15-41.pdf.

Gárate Rugel, C. I., Cardoso Suter, S., 2018. Tesis. Found on http://dspace.ucuenca.edu.ec/handle/123456789/31052.

UNESCO, 1982. Declaración de México de sobre las políticas culturales, Conferencia mundial sobres las políticas culturales, México D.F; Downloaded on the 20th of May 2017 from www.culturalrights.net/descargas/drets_culturals400.pdf.

Velecela, M., 2008. Arquitectura vernácula, del Pachamama al Cojitambo. Tesis previa a la obtención del título de Magister en Conservación de Monumentos y Sitios, Facultad de Arquitectura de la Universidad de Cuenca, p. 4-7. Cardoso Lyon.

Wikipedia: Concepto de Minka. Downloaded: https://es.wikipedia.org/wiki/Minka (15 February 2019). 